\title{
Antarctic phytoplankton assemblage in the western Bransfield Strait region, February 1993: composition, biomass, and mesoscale distributions
}

\author{
Sung-Ho Kang*, SangHoon Lee
}

Polar Research Center, Korea Ocean Research and Development Institute (KORDI), Ansan PO Box 29, Seoul 425-600, Korea

\begin{abstract}
The Bransfield Strait region shows complex patterns of water circulation due to mixing of diverse water masses. Physicochemical properties of the different water types should affect the distribution, biomass, and species composition of the phytoplankton assemblages. We examined these features of phytoplankton in the western Bransfield Strait region during early February 1993. Diversity of the phytoplankton species was low. Only 5 or 6 species accounted for more than $95 \%$ of the total phytoplankton carbon biomass. Integrated phytoplankton biomass in the upper $100 \mathrm{~m}$ ranged from 407 to $3605 \mathrm{mg} \mathrm{C} \mathrm{m}$ (average $1906 \mathrm{mg} \mathrm{C} \mathrm{m}^{-2}$ ). Areas with the higher biomass values $(2000$ to $3500 \mathrm{mg} \mathrm{C}$ $\mathrm{m}^{-2}$ ) were located in the northern part of the study area including waters to the north of the South Shetland Islands, and were generally related to increased stability of the surface water originating from the Bellingshausen Sea featuring lower salinity $\left(33.69\right.$ to $33.78 \%$ ) and higher temperature $\left(1.89\right.$ to $\left.2.36^{\circ} \mathrm{C}\right)$. Distribution of autotrophic nanoflagellates $(<20 \mu \mathrm{m})$ showed a marked contrast to that of diatoms. Waters in the Bransfield Stralt region were characterized by a dominance of nanoflagellates such as Cryptomonas sp. and Phaeocystis antarctica (motile stage) accounting for $83 \%$ of the total phytoplankton carbon. In the Drake Passage area, however, diatoms such as the nanoplanktonic Fragilariopsis pseudonana and the microplanktonic $(>20 \mu \mathrm{m}$ ) Rhizosolenia antennata f. semispina accounted for $84 \%$ of the total phytoplankton carbon. From measurements of upper ocean physical parameters and nutrients in combination with the data on composition, biomass, and distribution of the major phytoplankton species, it was found that mesoscale distributions of phytoplankton species reflect the physical conditions of the upper water column, particularly the profile of vertical stability of the water.
\end{abstract}

KEY WORDS: Antarctic phytoplankton Bransfield Strait Cryptomonas sp. Phaeocystis antarctica (motile stage)

\section{INTRODUCTION}

Special attention has recently been directed to the Antarctic ecosystem because of concerns regarding global environmental problems. The Southern Ocean is subjected to enhanced levels of ultraviolet-B (UV-B) radiation (290 to $320 \mathrm{~nm}$ ) due to the ozone depletion over Antarctica in the austral spring (Weiler \& Penhale 1994). This may already have affected phytoplankton activities in the Antarctic marine ecosystems (Karentz et al. 1991, Smith et al. 1992, Holm-Hansen et al. 1993). Jacobs \& Comiso (1993) have recently shown that the sea-ice minima in the Bellingshausen Sea during the

•E-mail: shkang@sari.kordi.re.kr years $1989-1991$ receded to $1 / 3$ of the average minima during the years $1973-1986$. This summer decrease in ice extent apparently is related to climatic changes, as surface air temperatures reached historic highs along the west coast of the Antarctic peninsula in 1989. Such changes in ice cover and air temperatures are likely to result in regional changes in hydrography

Such environmental changes, i.e. strong UV-B, little sea ice, or a 'warm' surface layer, may cause shifts in the taxonomic structure of Antarctic phytoplankton communities. Changes of the community structure could be accompanied by changes in the availability and nutritional value of the primary food sources, ultimately altering the transfer of energy between trophic levels. If there are changes of phytoplankton species 
composition and size distribution, changes to trophic interactions are likely to occur.

Phytoplankton assemblages in different or changing environments may have different representative species. These representative species or environmentally sensitive 'indicator' species may help to distinguish hydrographic regimes and to construct long-term monitoring systems for environmental changes in the Southern Ocean ecosystem (Marchant \& Davidson 1992). Species-specific information is a prerequisite for understanding ecological structure and processes in Antarctic waters.

Recent studies have found that autotrophs other than diatoms often dominate Antarctic phytoplankton assemblages and that the species composition, biomass, and distribution show large seasonal and regional variations (Hewes et al. 1985, Smetacek et al. 1990, Kang \& Fryxell 1992, 1993). A number of physical, chemical, or biological factors seem to regulate the species composition, biomass, and distribution of phytoplankton in space and time. A few examples of such factors are vertical stability of the water column (Mitchell \& Holm-Hansen 1991), light limitation in well-mixed waters (Mitchell et al. 1991), and availability of trace nutrients (Martin et al. 1990). In addition, Helbling et al. (1993) reported that the distribution, biomass, and species composition of the phytoplankton in the northern Bransfield Strait area intimately reflect physical oceanographic conditions and the proximity of the shelf-break and continental slope.

Biological factors such as grazing by zooplankton can also affect the phytoplankton assemblages. High krill abundances to the north of the South Shetland Islands were associated with the abundance of phytoplankton in frontal systems over the continental slope and shelf-breaks (Brinton 1991, Hewitt \& Demer 1993. Loeb et al. 1993). Since krill selectively feed on microsized (>20 $\mu \mathrm{m}$ ) phytoplankton (Quetin \& Ross 1985. Granéli et al. 1993), this krill distribution pattern may in part be determined by composition and size of phytoplankton, and the selective grazing in turn could result in a change of phytoplankton populations, leaving behind a nanoplankton-dominated crop (Kopczynska 1992, Villafañe et al. 1993).

The oceanographic research of the 6th Korean Antarctic Research Program (KARP) during the 1992-93 field season was designed to investigate relationships between physical, chemical, and biological parameters, and their mesoscale differences in the western Bransfield region. The study area includes the coastal shelf, the continental shelf break, island shelves, and deep waters of the Drake Passage, and is characterized by complex physical circulation, involving waters from the Bransfield Strait, Weddell Sea, Bellingshausen Sea, and Drake Passage. Comprehen- sive hydrographic surveys in this area conducted over the 4 mo U.S. RACER field program (1986-87) showed the presence of several different water masses and 2 major frontal structures (Niiler et al. 1991). Studies of the distribution and abundance of phytoplankton in this study area showed that the initiation, continuation, and demise of the spring bloom are controlled largely by the physical conditions of the water column (HolmHansen \& Mitchell 1991, Mitchell \& Holm-Hansen 1991). However, little attention was given by these authors to species composition when investigating the importance of physical and chemical parameters on the phytoplankton populations

In our study, we examined phytoplankton species composition and biomass, and described their mesoscale distributions in relation to hydrography and nutrient concentrations. We found that mesoscale distributions of phytoplankton species reflect the physical conditions of the water column. It is anticipated that this study will provide a good database for insights regarding the mechanisms which result in different distributions of key phytoplankton species and in structural alterations of planktonic assemblages.

\section{MATERIALS AND METHODS}

Sample collection. Phytoplankton assemblages in the western Bransfield Strait region were sampled during early February 1993 aboard the RV 'Onnuri' of the Korea Ocean Research \& Development Institute (KORDI). Data were acquired at 21 stations along 2 north-south transects spanning from Gerlache Strait to Drake Passage (Fig. 1). The transects extend from the coastal shelf to the deep waters of Drake Passage, crossing the continental shelf break and slope, and island shelves. The northern portion of the study area (Stns 9 to 11 in Transect 1 and Stns 19 to 21 in Transect 2) was located in the deep waters ( $>1000 \mathrm{~m}$ ) of Drake Passage. The southern portion of the study area (Stns 1 to 8 in Transect 1 and Stns 12 to 18 in Transect 2) was located in Bransfield Strait. We attempted to compare 2 of the 'station lines' which constituted the U.S. RACER studies in 1986-1987 (see Fig. 5 in Huntley et al. 1991).

Salinity and temperature were measured with a Mark $V$ conductivity-temperature-depth (CTD) profiler (General Oceanics, Inc., Miami, FL, USA). Water samples were obtained with a CTD/rosette unit at 7 discrete depths $(0,10,20,30,50,75$ and $100 \mathrm{~m})$ in 51 PVC Niskin bottles during the 'up' casts. Aliquots of $125 \mathrm{ml}$ were preserved with glutaraldehyde (final concentration 1\%). Samples were also collected via phytoplankton net tows (20 $\mathrm{\mu m}$ mesh) and preserved with glutaraldehyde (final concentration $2 \%$ ); these samples were for the analysis of rare species in the phytoplankton assemblage. 
Fig. 1. (A) Location of the sampling area and the major water masses. The main directions of surface water movement (after Hofmann et al. 1992) are shown by the arrows (B) Locations of the 21 stations, which were occupied during the $3 \mathrm{~d}$ 'fast grid' from 5 to 7 February 1993. The dashed line in Drake Passage indicates the continental shelf break
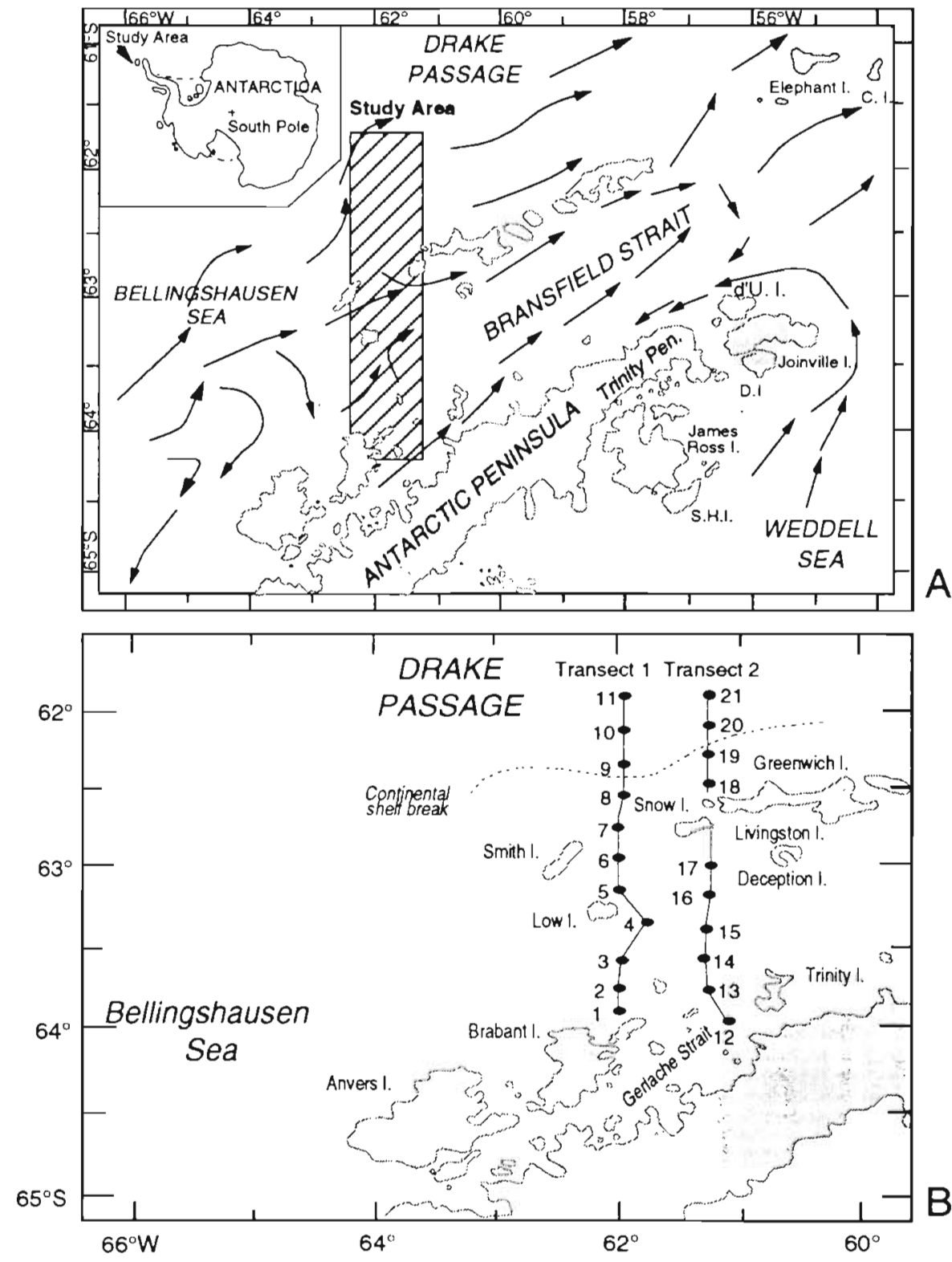

Sample volumes of 50 to $100 \mathrm{ml}$ were filtered through Gelman GN-6 Metricel filters $(0.45 \mu \mathrm{m}$ pore size, 25 mm diam.; Gelman Sciences, Inc., Ann Arbor, MI, USA). The filters were mounted on microscope slides with water-soluble embedding medium (HPMA, 2-hydroxypropyl methacrylate) on board the RV 'Onnuri'. The HPMA slides were used for estimating cell concentration and biomass. The HPMA-mounting technique, first described by Crumpton (1987), has some advantages over the classical Utermöhl sedimentation method (Kang et al. 1993b).

Cell count, biovolume, and biomass of phytoplankton. At least 300 cells were enumerated using a Zeiss Axiophot microscope, with the combination of light and epifluorescence microscopy at $400 \times$ for micro- plankton, and at $1000 \times$ for autotrophic pico- and nanoplankton (Booth 1993). For species that could not be identified under the light microscope, a Philips 515 scanning electron microscope (SEM; Polar Research Center, KORDI) was used. Autotrophic pico- and nanoflagellates were filtered, dehydrated, and critical point dried according to the standard methods (Dykstra 1992). Whole mounts coated with gold were used for the SEM.

Conversions from the raw cell counts to cell concentrations were done as described previously by Kang \& Fryxell (1991) and Kang et al. (1993a). Cell dimensions of dominant phytoplankton species were measured to the nearest $1 \mu \mathrm{m}$ for subsequent estimations of biovolume using appropriate geometric shapes (Smayda 
1978). The carbon biomass was estimated from the cell biovolume with the modified Strathmann equations (Eqs. 7 and 8 in Smayda 1978) For autotrophic flagellates, the relationship $\log _{10}[$ carbon $(p g)]=0.94 \log _{10}$ (cell volume $\left.\left(\mu \mathrm{m}^{3}\right)\right]-0.60$ was used, and for diatoms, $\log _{10}[$ carbon $(\mathrm{pg})]=0.76 \log _{10}\left[\right.$ cell volume $\left.\left(\mu \mathrm{m}^{3}\right)\right]-0.352$.

Cluster analysis. Biomass values of the phytoplankton assemblages were compared among stations and depths via cluster analysis using SYSTAT for Macintosh in order to examine relationships between stations and transects. Biomass values of dominant phytoplankton species integrated in the upper $100 \mathrm{~m}(\mathrm{mg} \mathrm{C}$ $\mathrm{m}^{-2}$ ) were used as variables, and stations were grouped by an average-linkage clustering method. We reduced the number of variables by selecting the most abundant phytoplankton groups and species in order to facilitate the interpretation of results and avoid the problem of including rare species as discussed by Gould (1987).

Inorganic nutrients and chlorophyll analysis. For inorganic nutrients and chl a measurements, water samples $(500 \mathrm{ml})$ were filtered through a $47 \mathrm{~mm}$ glass fiber filter $(\mathrm{GF} / \mathrm{F})$ and the filtrates were stored frozen in acid-cleaned polyethylene bottles at $-45^{\circ} \mathrm{C}$. The samples were kept frozen with dry ice during transport to KORDI. Later in the lab, nutrient concentrations were
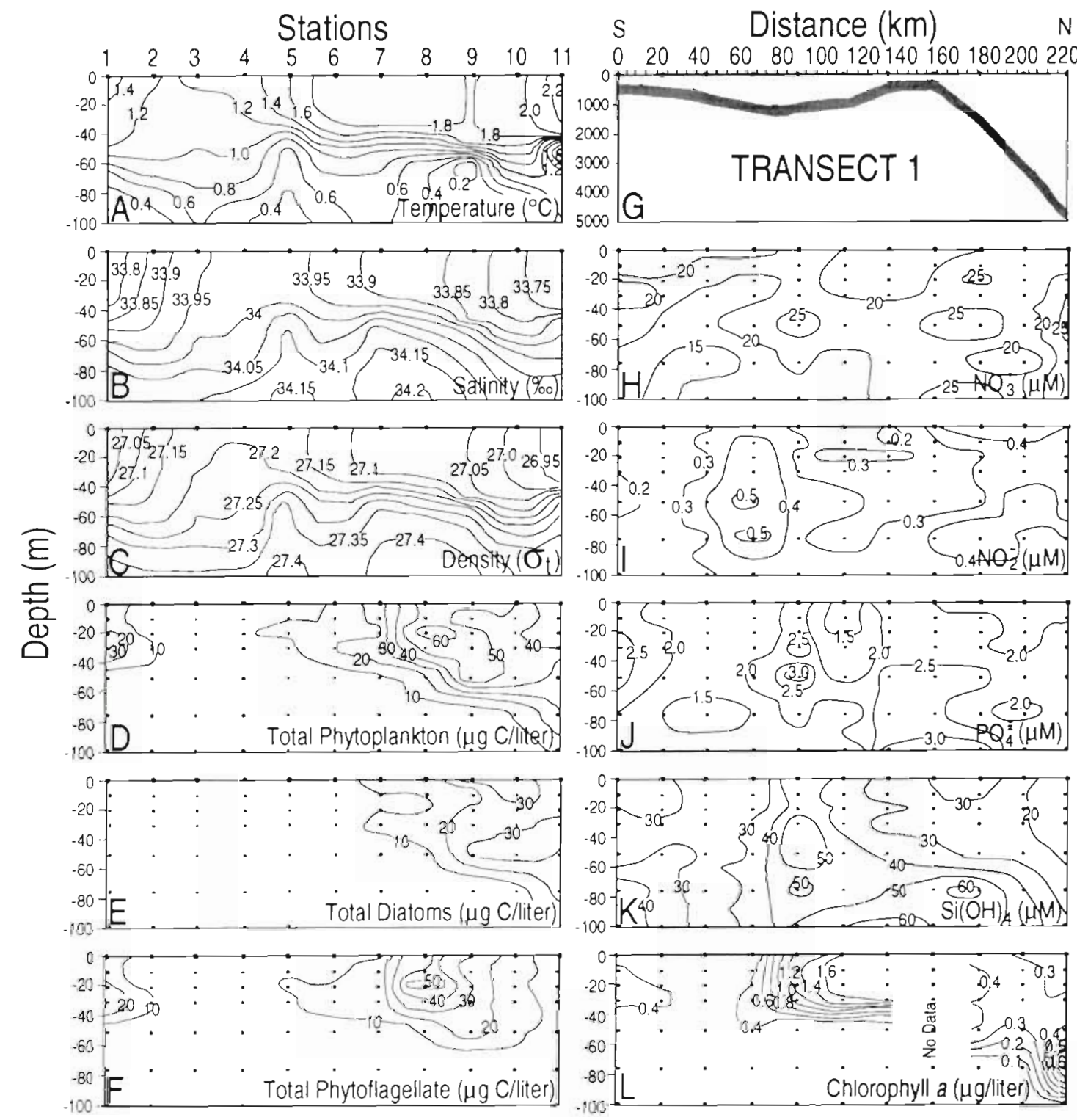

Fig. 2. Vertical sections of hydrography, nutrient concentration, and phytoplankton biomass in the upper $100 \mathrm{~m}$ along Transect 1 (A) Temperature, (B) salinity, (C) density, (D) total phytoplankton carbon biomass, (E) diatom carbon biomass, (F) autotrophic flagellate carbon biomass, (G) bottom contour, (H) mitrate, (I) nitrite, (J) phosphate, (K) silicate, (L) chlorophyll a 
determined with a Technicon Autoanalyser II by the method described in Grasshoff et al. (1983), and chl a concentrations ( 3 samples per station) were determined by the extraction method of Holm-Hansen \& Riemann (1978). In vivo fluorescence was determined immediately on board with a Turner Design field fluorometer (Model 10-005R), and converted to chl a by using the correlation between the two. In order to obtain a calibration factor to convert the in vivo fluorescence signal to absolute concentrations of chl a, 3 water samples were taken at every station to determine extracted chl a concentrations. The $r^{2}$ value of the correlation was $0.83(n=63)$.

\section{RESULTS}

\section{Hydrography}

The hydrographic features of the upper water column varied both horizontally and vertically. Surface water temperatures varied from $1.2^{\circ} \mathrm{C}$ in the southern portion to $>2.0^{\circ} \mathrm{C}$ in the northern portions (Figs. 2A \& $3 \mathrm{~A}$ ). Surface salinity was between 33.65 and $34 \%$, with the lower values at the southern end and in the northern portions of the transects (Figs. 2B \& 3B). As indicated by the similar patterns of isopleths in Figs. $2 \& 3$, vertical and horizontal structures of the surface water
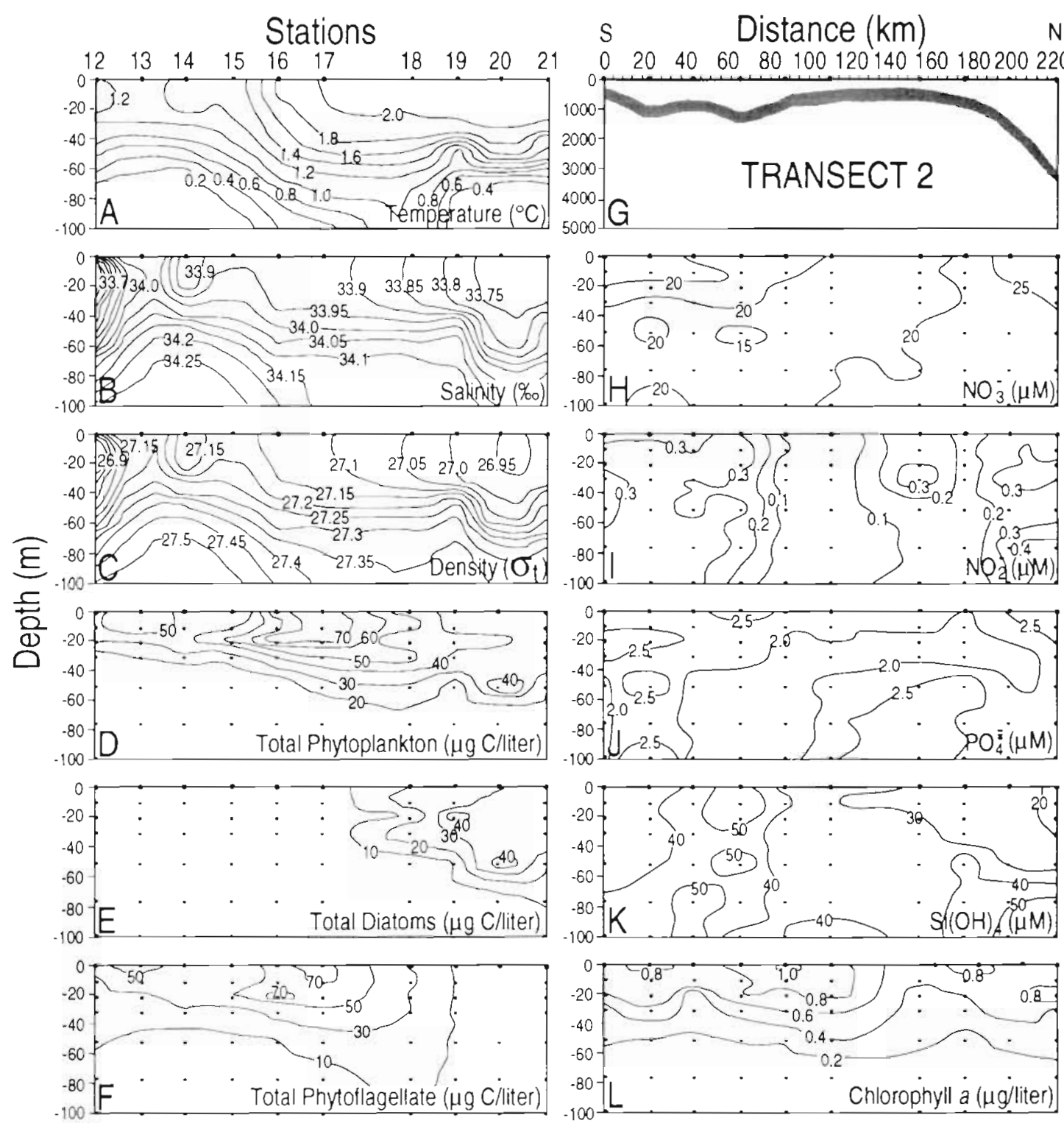

Fig. 3. Vertical sections of hydrography, nutrient concentration, and phytoplankton biomass in the upper $100 \mathrm{~m}$ along Transect 2. $(A-L)$ as for Fig. 2 
properties were closely related to the distribution patterns of phytoplankton. Stations near the Gerlache Strait (Stns 1, 12), on the continental shelf off Snow and Livingston Islands (Stns 7, 8, 9, 16-18), and in the southern Drake Passage (Stns 10, 11, 19-21) showed distinct pycnoclines between 40 and $60 \mathrm{~m}$ with density gradients $(0.32$ to 0.63$)$ from 0 to $100 \mathrm{~m}$ (Figs. $2 \mathrm{C} \& 3 \mathrm{C})$. Phytoplankton concentrations were high above the pycnoclines but decreased rapidly below them (Figs. 2D-F \& 3D-F). This suggests the distributions of phytoplankton parameters were causally related to the hydrographical parameters, as discussed later.

\section{Phytoplankton carbon estimates}

Phytoplankton cell abundance (PPA) and carbon biomass (PPC) were integrated per $\mathrm{m}^{2}$ for the upper $100 \mathrm{~m}$ (Fig, 4). The integrated PPA (Fig. 4A, B) and PPC (Fig. 4C, D) ranged from $8.5 \times 10^{10}$ to $5.9 \times 10^{11} \mathrm{cells} \mathrm{m}^{-2}$ (average $2.68 \times 10^{11}$ cells $\mathrm{m}^{-2}$ ) and from 407 to 3605

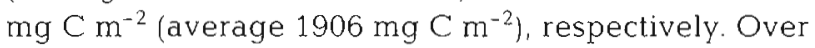
45 phytoplankton species were found in the western Bransfield Strait region during the study period (see the list of species in Kang et al. 1993b); however, only 5 or 6 phytoplankton species accounted for $95 \%$ of the total PPC (Table 1). Averaged over the entire study area, unidentified autotrophic picoflagellates $(\sim 1.5 \mu \mathrm{m})$ were the most abundant species, being about $41 \%$ of the total PPA. However, they accounted for only $6 \%$ of the total PPC (Table 1 ) because of their small cell volume. In contrast to the picoflagellates, the larger-celled $(>20 \mu \mathrm{m})$ diatom species such as Rhizosolenia antennata $f$. semispina Sundström was only $0.01 \%$ of the total PPA, but accounted for $11 \%$ of the total PPC. For food web concerns, PPC is the more relevant measurement and was thus used for the analysis of the phytoplankton distribution patterns.

\section{Mesoscale distribution patterns of the dominant phytoplankton species and biomass}

PPC was generally high near the shelves of Snow and Livingston Islands in Bransfield Strait and in Drake Passage waters (Figs. 2D \& 3D). The distribution pattern of PPC resembles the vertical and horizontal structure of the density field. High PPC (>30 $\left.\mu \mathrm{g} \mathrm{Cl}^{-1}\right)$ was usually found in vertically stratified waters above the pycnocline (Figs. 2C, D \& 3C, D); the surface mixed layer was characterized by lower salinities $(<34 \%)$ and higher temperature $\left(>1.3^{\circ} \mathrm{C}\right.$ ) (Fig. 5). The increased PPC was mainly due to the dominance of the autotrophic nanoflagellates Cryptomonas sp. and Phaeocystis antarctica Karsten in motile stage (see new nomenclature on this species in Medlin et al. 1994) (Fig. 6A, B) and diatoms such as Fragilariopsis pseudonana (Hasle) Hasle and Rhizosolenia antennata f. semispina (Fig. 6C, D).

Waters in the Bransfield Strait region (Stns 1 to 8 in Transect 1 and Stns 12 to 18 in Transect 2) were characterized by a dominance of autotrophic nanoflagellates $(<20 \mu \mathrm{m})$ that accounted for $83 \%$ of the total PPC (Figs, 2F, 3F \& 7A-F), while waters in the north of the study area (Stns 9 to 11 in Transect 1 and Stns 19 to 21 in Transect 2) showed a dominance of diatoms that accounted for $84 \%$ of the total PPC (Figs. 2E, 3E \& $7 \mathrm{G}-\mathrm{N})$. The autotrophic nanoflagellates Cryptomonas sp. and Phaeocystis antarctica (motile) were important carbon contributors among flagellates. The biomass of Cryptomonas sp. ranged from 10 to $60 \mu \mathrm{g} \mathrm{Cl}^{-1}$ in the surface $50 \mathrm{~m}$ (Fig. 7A, B), accounting for about $37 \%$ of total PPC (Table 1). P. antarctica was the second most important carbon contributor among flagellates, accounting for $13 \%$ of the total PPC.

Diatom biomass was higher in the northern part of the study area than in the southern part (Fig. $7 \mathrm{G}-\mathrm{N}$ ). The nanoplanktonic $(<20 \mu \mathrm{m})$ diatom Fragilariopsis

Table 1 Ten phytoplankton taxa rankıng highest in abundance and carbon biomass in the western Bransfield Strait region

\begin{tabular}{|c|c|c|c|}
\hline Phytoplankton & $\begin{array}{l}\text { Relative abundance } \\
\text { (\% frequency of cells) }\end{array}$ & \multicolumn{2}{|c|}{$\begin{array}{l}\text { Relative blomass } \\
\text { (\% contribution of total biomass) }\end{array}$} \\
\hline Autotrophic picoflagellates & 40.7 & Cryptomonas sp. & 37.1 \\
\hline Phaeocystis antarctica (motile) & 31.8 & Fragilariopsis pseudonana & 25.8 \\
\hline Cryptomonas sp. & 15.6 & Phaeocystis antarctica (motile) & 13.4 \\
\hline Fragilariopsis pseudonana & 7.3 & Rhizosolenia antennata f semispina & 10.5 \\
\hline Archaemonads & 2.4 & Autotrophic picoflagellates & 5.7 \\
\hline Unidentified flagellate $(-5 \mu \mathrm{m})$ & 0.14 & Fragilariopsis spp. (girdle) (>10 um) & 2.8 \\
\hline Fragllariopsis spp. (girdle) $(>10 \mu \mathrm{m})$ & 0.1 & Unidentified flagellate $(-5 \mu \mathrm{m})$ & 2.3 \\
\hline F. cylindrus & 0.04 & Archaemonads & 1.0 \\
\hline Prorocentrum spp. & 0.014 & Asteromhalus hyalınus & 0.3 \\
\hline Rhizosolenia antennata f semispina & 0.01 & Chaetoceros criophilum & 0.2 \\
\hline Others & 1.81 & Others & 0.89 \\
\hline
\end{tabular}



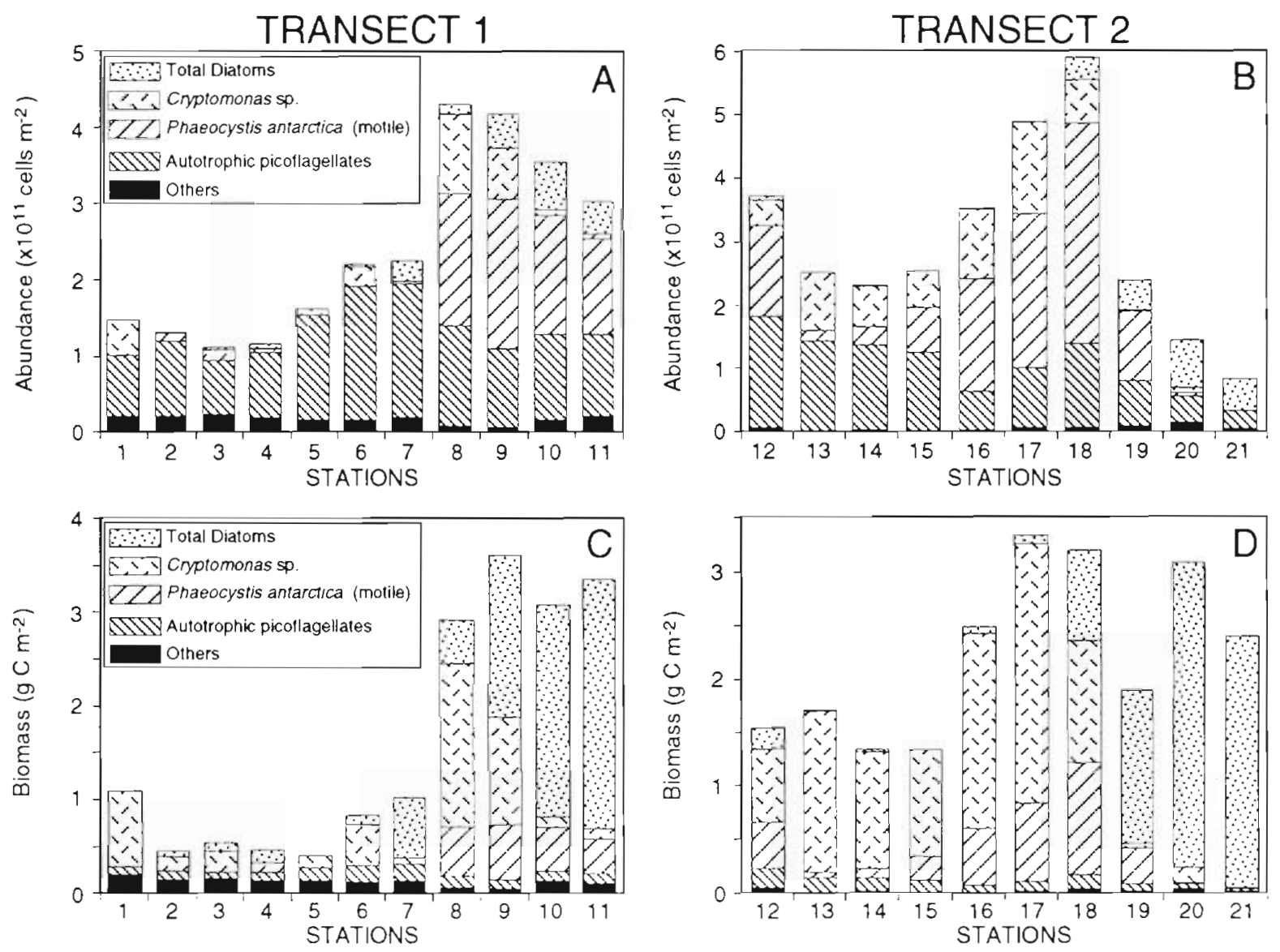

Fig. 4. $(\mathrm{A}, \mathrm{B})$ Abundance $\left(\times 10^{11}\right.$ cells $\left.\mathrm{m}^{-2}\right)$ and $(\mathrm{C}, \mathrm{D})$ biomass $\left(\mathrm{g}\right.$ carbon $\left.\mathrm{m}^{-2}\right)$ of total diatoms, Cryptomonas sp., Phaeocystis antarctica (motile), autotrophic picoflagellates, and other phytoplankton integrated in the upper $100 \mathrm{~m}$ at Stns 1 to 11 along Transect 1 and Stns 12 to 21 along Transect 2

pseudonana, which forms ribbon-shaped colonies by abutting the valve surfaces (Fig. 6C), was the most important carbon contributor among diatoms. Although $F$. pseudonana cells were distributed more widely to the south as compared to the other species of diatoms, the distribution was still mainly in the northern portion of the study area. The biomass of $F$. pseudonana ranged from 5 to $25 \mu \mathrm{g} \mathrm{Cl}^{-1}$ in the surface $50 \mathrm{~m}$ (Fig $7 \mathrm{G}, \mathrm{H}$ ) and accounted for $26 \%$ of the total PPC (Table 1), making it the second most important species in regard to organic carbon. Although individual cells of $F$. pseudonana are nanoplanktonic ( 8 to $10 \mu \mathrm{m}$ in length), the chains of individual cells form micro-sized particles which may be favored as food by some zooplankton.

Micro-sized diatoms ( $>20 \mu \mathrm{m}$ ) such as Chaetoceros criophilum Castracane, Corethron criophilum Castracane, and Rhizosolenia antennata f. semispina were also important carbon contributors among diatoms (Fig. 7I-N). R. antennata f, semispina (Fig. 6D) showed the highest carbon value ( $>15 \mu \mathrm{g} \mathrm{Cl}^{-1}$ ) at the northern-

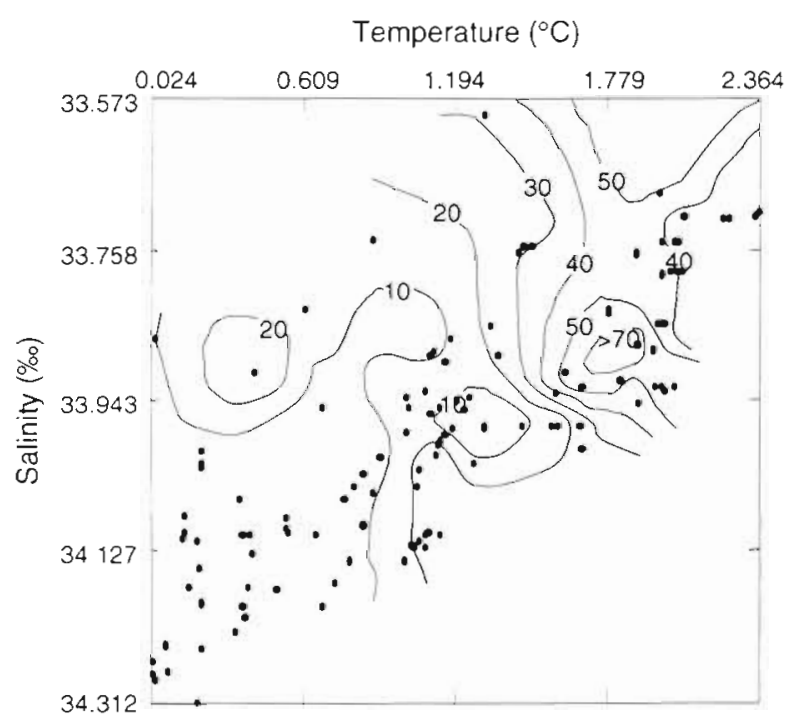

Fig. 5. Isopleths of total phytoplankton carbon ( $\mu \mathrm{C} \mathrm{C}^{-1}$ ) on the temperature-salinity diagram for all the samples used in this study 


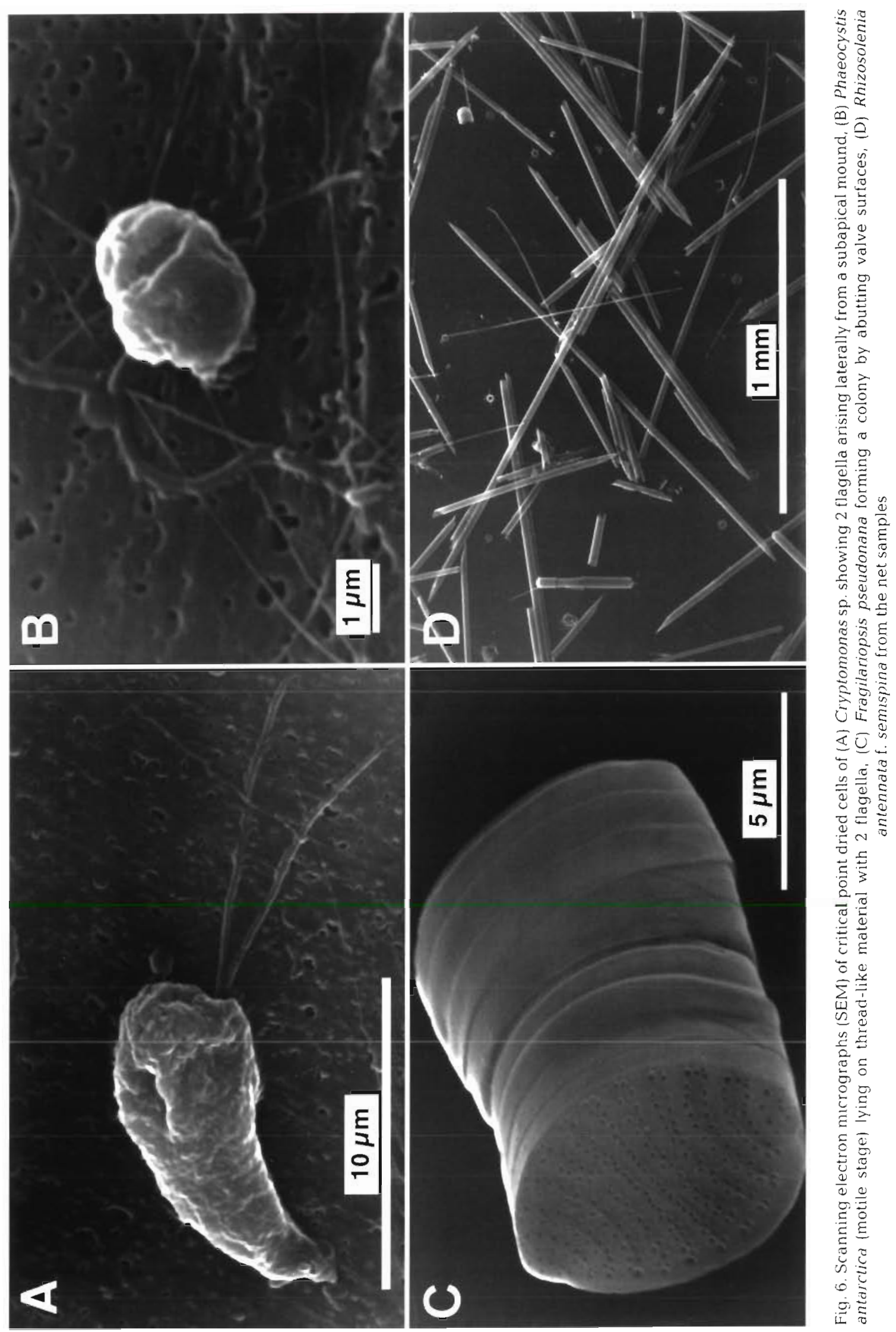


Stations
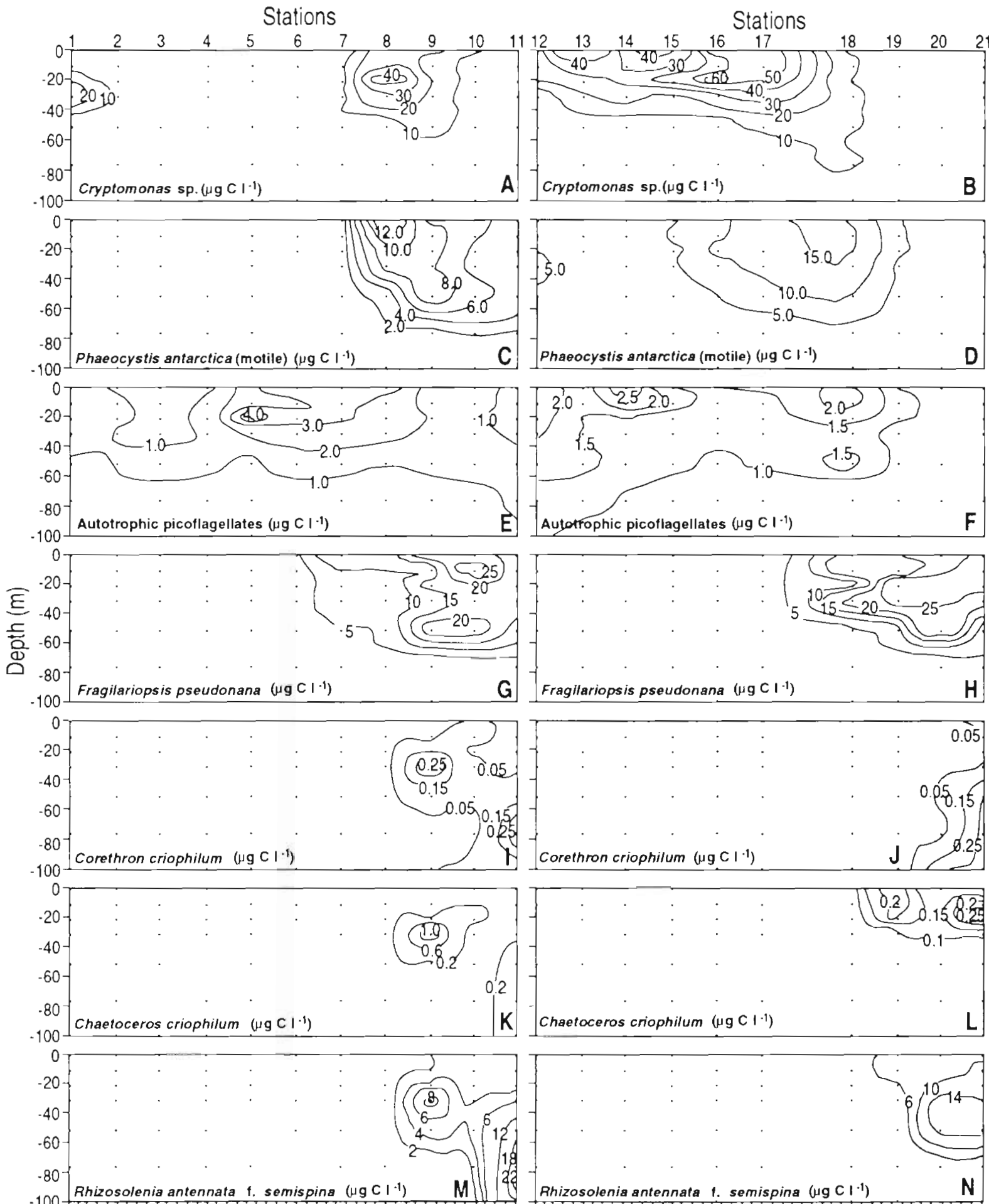

100 Rhizosolenia antennata $\mathrm{f}$ semispina $(\mu \mathrm{g} \mathrm{C} \mathrm{I}$

Rhizosolenia antennata 1. semispina $\left(\mu \mathrm{g} \mathrm{Cl}^{-1}\right)$

$\mathrm{N}$

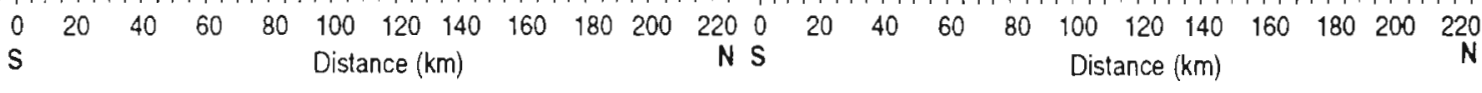

TRANSECT 1

TRANSECT 2

Fig. 7 Vertical sections showing the biomass of various phytoplankton species in the upper $100 \mathrm{~m}$ along both transects. (A, B)

Cryptomonas sp.; (C, D) Phaeocystis antarctica (motile); (E, F) autotrophic picoflagellates; $(\mathrm{G}, \mathrm{H})$ Fragilariopsis pseudonana; $(\mathrm{I}, \mathrm{J})$ Corethron criophilum; (K, L) Chaetoceros criophilum; (M, N) Rhizosolenia antennata f. semispina 
Table 2. Pearson correlation matrix of biological or environmental parameters from the top $100 \mathrm{~m}$. Temp: temperature; Sal: salinity; Den: density; $\mathrm{NO}_{3}$ : nitrate: $\mathrm{PO}_{4}$ : phosphate; $\mathrm{SiOH}_{4}$ : silicate; Chl: chlorophyll a; Fla: total phytoflagellate carbon; Cryp: Cryptomonas sp. carbon; Phaeo: Phaeocystis antarctica (motile cell) carbon; Dia: total diatom carbon; FP: Fragilariopsis pseudonana carbon; RH: Rhizosolenia antennata f. semispina carbon; PPC: total phytoplankton carbon. $R$ values shown are significant ( $\mathrm{p} \leq 0.05)$; values where $p>0.05$ are not presented

\begin{tabular}{|c|c|c|c|c|c|c|c|c|c|c|c|c|c|c|}
\hline & Temp & Sal & Den & $\mathrm{NO}_{3}$ & $\mathrm{PO}_{4}$ & $\mathrm{SiOH}_{4}$ & Chl & Fla & Cryp & Phaeo & Dia & $\mathrm{FP}$ & RH & PPC \\
\hline Temp & - & - & - & - & - & - & - & - & - & - & - & - & - & - \\
\hline Sal & -0.762 & - & - & - & - & - & - & - & - & - & - & - & - & - \\
\hline Den & -0.862 & 0.985 & - & - & - & - & - & - & - & - & - & - & - & - \\
\hline $\mathrm{NO}_{3}$ & & & & - & - & - & - & - & - & - & - & - & - & - \\
\hline $\mathrm{PO}_{4}$ & & & & 0.753 & - & - & - & - & - & - & - & - & - & \\
\hline $\mathrm{SiOH}_{4}$ & -0.527 & 0.507 & 0.539 & & 0.229 & - & - & - & - & - & - & - & - & - \\
\hline Chl & 0.511 & -0.269 & -0.345 & & & & - & - & - & - & - & - & - & - \\
\hline Fla & 0.415 & -0.23 & -0.289 & & & & 0.492 & - & - & - & - & - & - & - \\
\hline Cryp & 0.322 & & -0.2 & & & & 0.49 & 0.977 & - & - & - & - & - & - \\
\hline Phaeo & 0.48 & -0.309 & -0.372 & & & -0.169 & & 0.651 & 0.494 & - & - & - & - & - \\
\hline Dia & 0.537 & -0.57 & -0.593 & 0.253 & & -0.491 & & & & 0.26 & - & - & - & - \\
\hline FP & 0.581 & -0.551 & -0.591 & 0.201 & & -0.488 & & & & 0.31 & 0.954 & - & - & - \\
\hline $\mathrm{RH}$ & 0.246 & -0.363 & -0.352 & 0.356 & & -0.367 & & & -0.176 & & 0.727 & 0.543 & - & - \\
\hline PPC & 0.663 & -0.524 & -0.588 & & & -0.323 & 0.401 & 0.818 & 0.757 & 0.706 & 0.523 & 0.518 & 0.279 & - \\
\hline
\end{tabular}

most stations (Stn 11 in Transect 1 and Stn 21 in Transect 2) near the pycnocline (Fig. 7M, N). The higher carbon values by the larger-celled diatoms found near the pycnocline seem to be the result of the cell accumulation at the pycnocline, where density differences across the pycnocline minimize settling of cells.

\section{Relationship to chl $a$ and nutrients}

Chl a concentrations ranged from 0.01 to $1.72 \mu \mathrm{g} \mathrm{l}^{-1}$ in the surface $100 \mathrm{~m}$. A positive correlation was found between chl a and PPC (Table 2). Mean chl a concentration in surface waters $\left(0.66 \mu \mathrm{g} \mathrm{l}^{-1}\right)$ during our study period was lower as compared to the monthly mean values of surface chl a concentrations in this area reported by Holm-Hansen \& Mitchell (1991); they reported 6.5, 4.6, 1.4, and $1.2 \mu \mathrm{g} \mathrm{l}^{-1}$ in December, January, February, and March, respectively.

In contrast to the relatively low chl a levels, overall nutrient concentrations were high in the surface $100 \mathrm{~m}$ (Figs. $2 \mathrm{H}-\mathrm{K} \& 3 \mathrm{H}-\mathrm{K}$ ). Nitrate and phosphate concentrations during the study period ranged from 8.6 to $39.3 \mu \mathrm{M}$ and 0.87 to $3.9 \mu \mathrm{M}$, respectively. Distributions of the nutrients were not significantly correlated with phytoplankton populations (Table 2). However, silicate concentrations, ranging from 7.4 to $68.0 \mu \mathrm{M}$, were significantly correlated with the PPC (Table 2). The PPC (especially of diatoms) maximum in the northern portion of the study area was associated with localized minima of the silicate concentrations (see Figs. 2E, K \& $3 E, K)$. The silicate concentrations in the northernmost stations of the Drake Passage area (Stn 11 in Transect 1 and Stn 21 in Transect 2), where diatom carbon was highest, were about 10 to $40 \mu \mathrm{M}$ less as compared to other stations. Coincidence of the diatom carbon maxima and the silicate minima indicates silicate uptake by diatoms such as Rhizosolenia antennata f. semispina, Chaetoceros criophilum, Corethron criophilum, and Fragilariopsis pseudonana.

\section{DISCUSSION}

A cluster analysis was done in order to examine the relationships among the stations and their hydrographic regimes. Stations were treated as cases and the variables were the integrated PPC $\left(\mathrm{mg} \mathrm{C} \mathrm{m}^{-2}\right)$ of total diatoms, Cryptomonas sp., Phaeocystis antarctica (motile), picoflagellates, and total phytoplankton.

The cluster analysis divided the study area into 4 groups (Fig. 8). Cluster I consists of the stations located in shallow coastal waters at the mouth of Gerlache Strait (Stns 1, 12-15), where the phytoplankton assemblage consisted mainly of Cryptomonas sp. $(<10 \mu \mathrm{m}$ in length) that accounted for about $72 \%$ of the total PPC in the Cluster I area (Table 3 ). The predominance of Cryptomonas sp. in Gerlache Strait has also been observed by others (Ferraria \& Sar 1992, Vernet 1992). Phaeocystis antarctica ( 2 to $3 \mu \mathrm{m}$ diameter) and the picoflagellates also accounted for a substantial portion of the total PPC (11 and 9.4\%, respectively). Diatoms accounted for only $3 \%$ of the total PPC. Mean of the integrated PPC in the upper $100 \mathrm{~m}$ was about $1400 \mathrm{mg} \mathrm{C} \mathrm{m} \mathrm{m}^{-2}$, and the phytoplankton consisted mainly of pico- and nanoflagellates in Cluster I stations ( $>95 \%$ of total PPC; Table 3). Dominance of autotrophic nanoflagellates in Antarctic waters has 

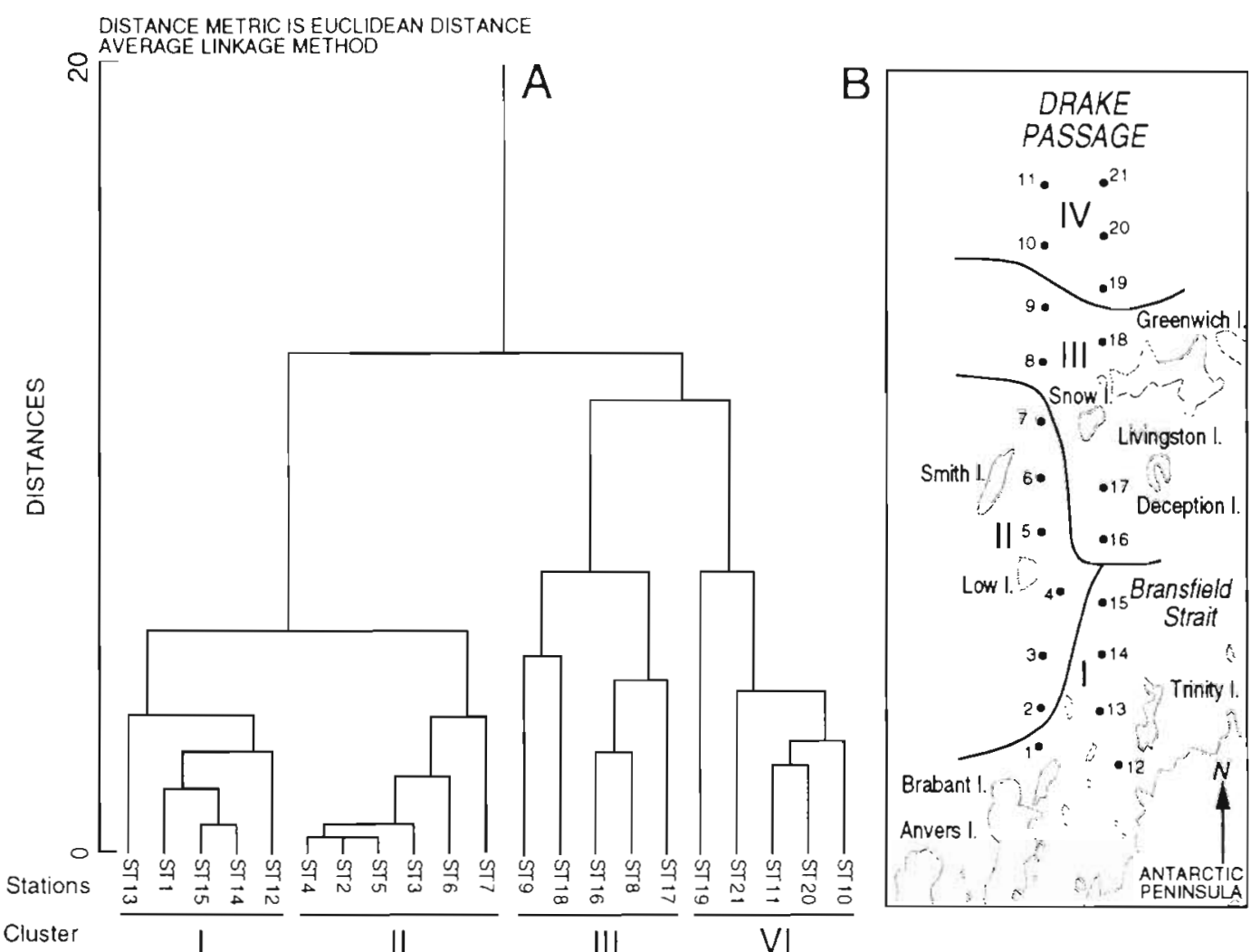

Fig. 8. (A) Dendrogram from the average-linkage cluster analysis on stations. Variables for the analysis were the integrated carbon of 5 major groups of phytoplankton. See 'Discussion' for details of the analysis. (B) Location of the clusters in the study area

also been observed by others (e.g. Nöthig et al. 1991, Buma et al. 1992, Kang et al. 1993b).

Relatively high primary productivity and phytoplankton biomass have been observed in Gerlache Strait by Holm-Hansen \& Mitchell (1991). They reported that the phytoplankton populations showed a distinctive seasonality during December to March. Massive blooms during December and January declined abruptly to low levels in February and March. Species composition shifted from predominantly microplankton in December to predominantly nanoplankton in February and March. Our data suggest that the phytoplankton observed during our study period in the Gerlache Strait region (Cluster I) was in a 'post-bloom' stage. Relatively low silicate concentrations $(-30 \mu \mathrm{M}$; Fig. $2 \mathrm{~K})$ coupled with low diatom biomass ( $<10 \mu g \mathrm{C}^{-1}$; Fig. 2E) also suggest a previous bloom of diatoms. Leventer (1991), who examined particle-trap sediments from the RACER program, also reported a dominance of micro-sized diatoms such as Chaetoceros sp. in December but a nanoplanktondominated phytoplankton assemblage in February and March.

Cluster II consists of the stations (Stns 2 to 7 ) around Low and Smith Islands located in the western entrance of Bransfield Strait. With the decrease of Cryptomonas sp. carbon biomass to about $31 \%$ of total PPC, both diatom biomass and picoflagellate biomass increased to about 28 and $20 \%$ of the total PPC, respectively (Table 3). Phaeocystis antarctica, however, contributed very little to the total phytoplankton carbon. The waters in the upper $100 \mathrm{~m}$ are characterized by small changes in temperature, salinity, and density (density gradients ranging between 0.16 and 0.26 from 0 to $100 \mathrm{~m}$; Fig. 9G), resulting in a vertically less stratified upper water column compared to the other stations. Intrusions of relatively cold and saline water from Drake Passage into Bransfield Strait were noted around Smith and Low Islands during an intensification of the cyclonic northern mesoscale pattern (Niiler et al. 1991). One explanation why mean total PPC was lowest in the stations of Cluster II $\left(613 \mathrm{mg} \mathrm{C} \mathrm{m}^{-2}\right.$; Table 3 ) is the destabilization of the upper water column (Mitchell \& Holm-Hansen 1991).

Cluster III includes the stations located on the continental shelf off Snow and Livingston Islands (Stns 8, 9, 16-18; Fig. 8). Niiler et al. (1991) reported that the Livingston Island area contains an indigenous pool of water, which appears to be isolated from other water sources. The waters in the upper $100 \mathrm{~m}$ are character- 


\begin{tabular}{|c|c|c|c|c|c|c|}
\hline 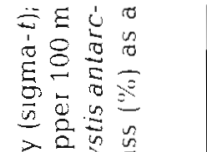 & 总 & 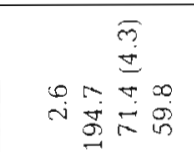 & 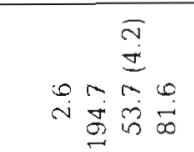 & 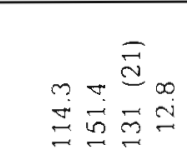 & 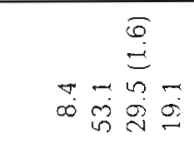 & 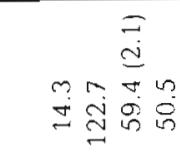 \\
\hline 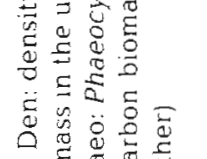 & $\frac{8}{2}$ & 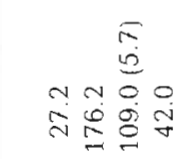 & 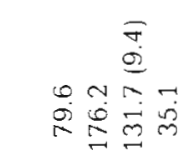 & 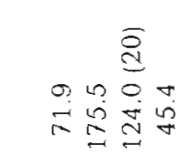 & 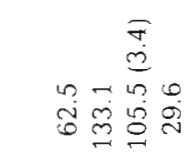 & 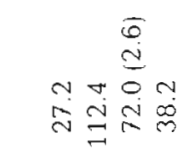 \\
\hline 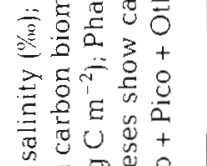 & $\begin{array}{l}0 \\
\frac{d}{2} \\
\frac{\pi}{2}\end{array}$ & 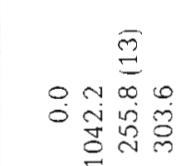 & 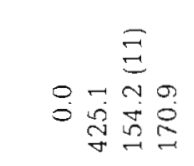 & 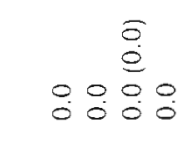 & 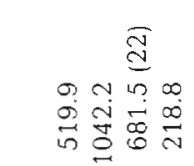 & 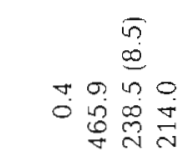 \\
\hline 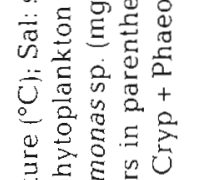 & 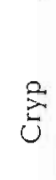 & 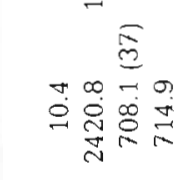 & 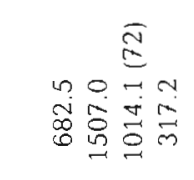 & 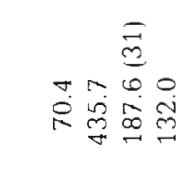 & 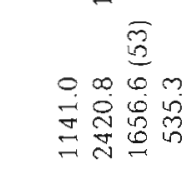 & 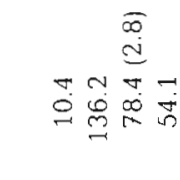 \\
\hline 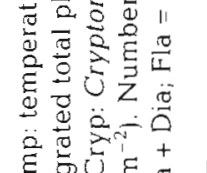 & $\stackrel{\pi}{0}$ & 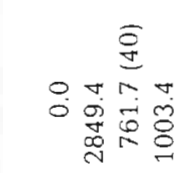 & 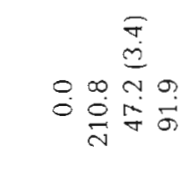 & 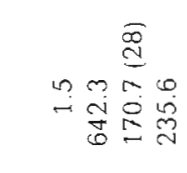 & 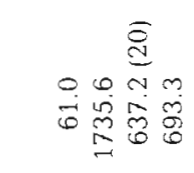 & 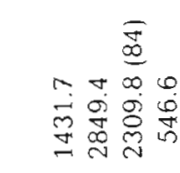 \\
\hline 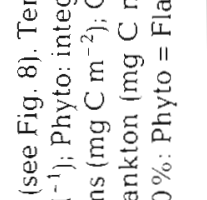 & $\frac{\pi}{\sqrt{1}}$ & 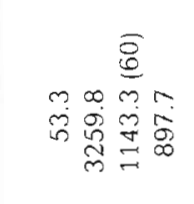 & 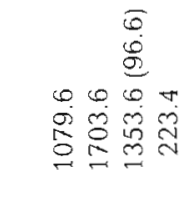 & 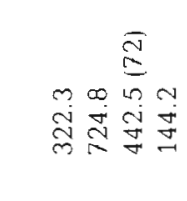 & 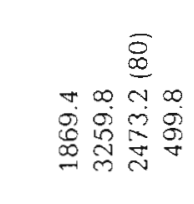 & 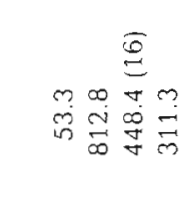 \\
\hline 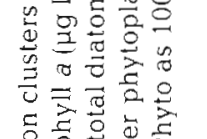 & $\frac{9}{2}$ & 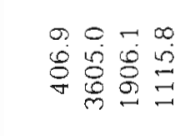 & 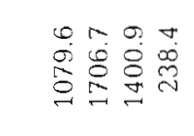 & 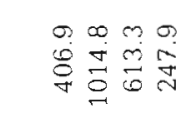 & 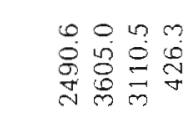 & 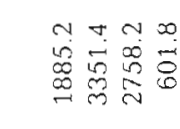 \\
\hline 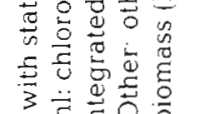 & $\vec{E}$ & 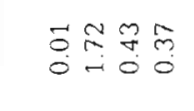 & 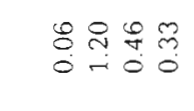 & $\begin{array}{lll}\overrightarrow{0} \cong & \vec{n} & \vec{n} \\
0 & -0 & 0\end{array}$ & 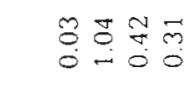 & 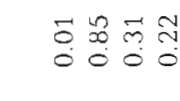 \\
\hline 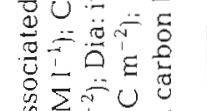 & $\stackrel{\vec{T}}{0}$ & 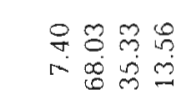 & 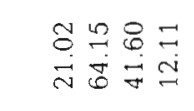 & 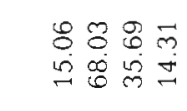 & 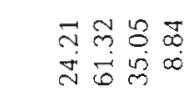 & 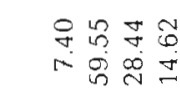 \\
\hline$\vec{\sigma}$ & 2 & 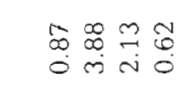 & 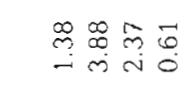 & 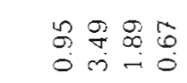 & 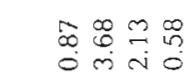 & 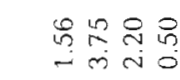 \\
\hline$\stackrel{\pi}{0} \frac{2}{0}$ & Z & 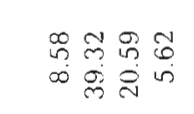 & 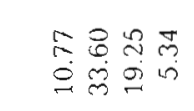 & 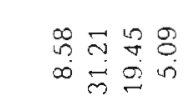 & 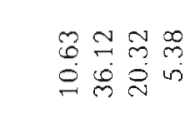 & 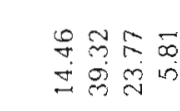 \\
\hline$\vec{E}$ & ป & 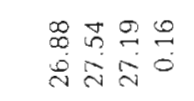 & 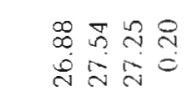 & 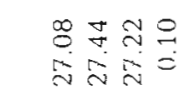 & 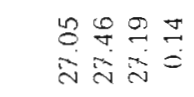 & 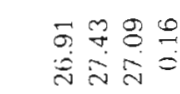 \\
\hline 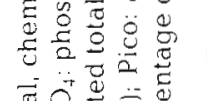 & $\begin{array}{l}\bar{\sigma} \\
\ddot{\omega}\end{array}$ & 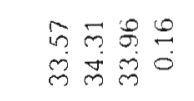 & 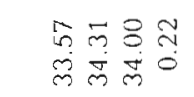 & 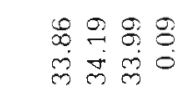 & 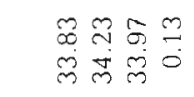 & 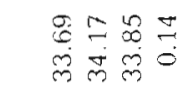 \\
\hline & 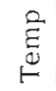 & 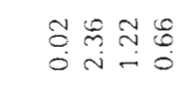 & 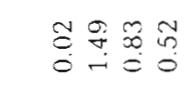 & $\begin{array}{l}\square \\
0 \\
0\end{array}$ & 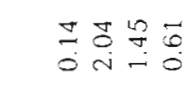 & 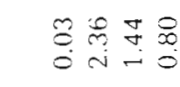 \\
\hline 总 & & 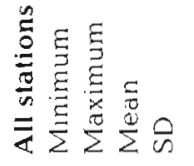 & 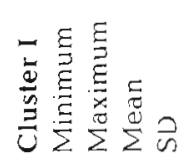 & 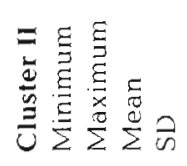 & 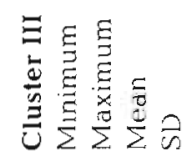 & 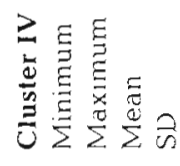 \\
\hline
\end{tabular}


ized by relatively high temperatures $\left(0.14\right.$ to $2.04^{\circ} \mathrm{C}$, average $1.45 \pm 0.61^{\circ} \mathrm{C}$ ) and low salinities (33.83 to $34.23 \%$, average $33.97 \pm 0.13 \%$ ), featuring density gradients between 0.27 and 0.38 from 0 to $100 \mathrm{~m}$, and the subsequent stabilization of the upper water column (Fig. 9I-L). The highest PPC was found at the stations in Cluster III (mean of $3111 \mathrm{mg} \mathrm{C} \mathrm{m}^{-2}$ ), and the mean total PPC was about 5 times higher than that of the sta-

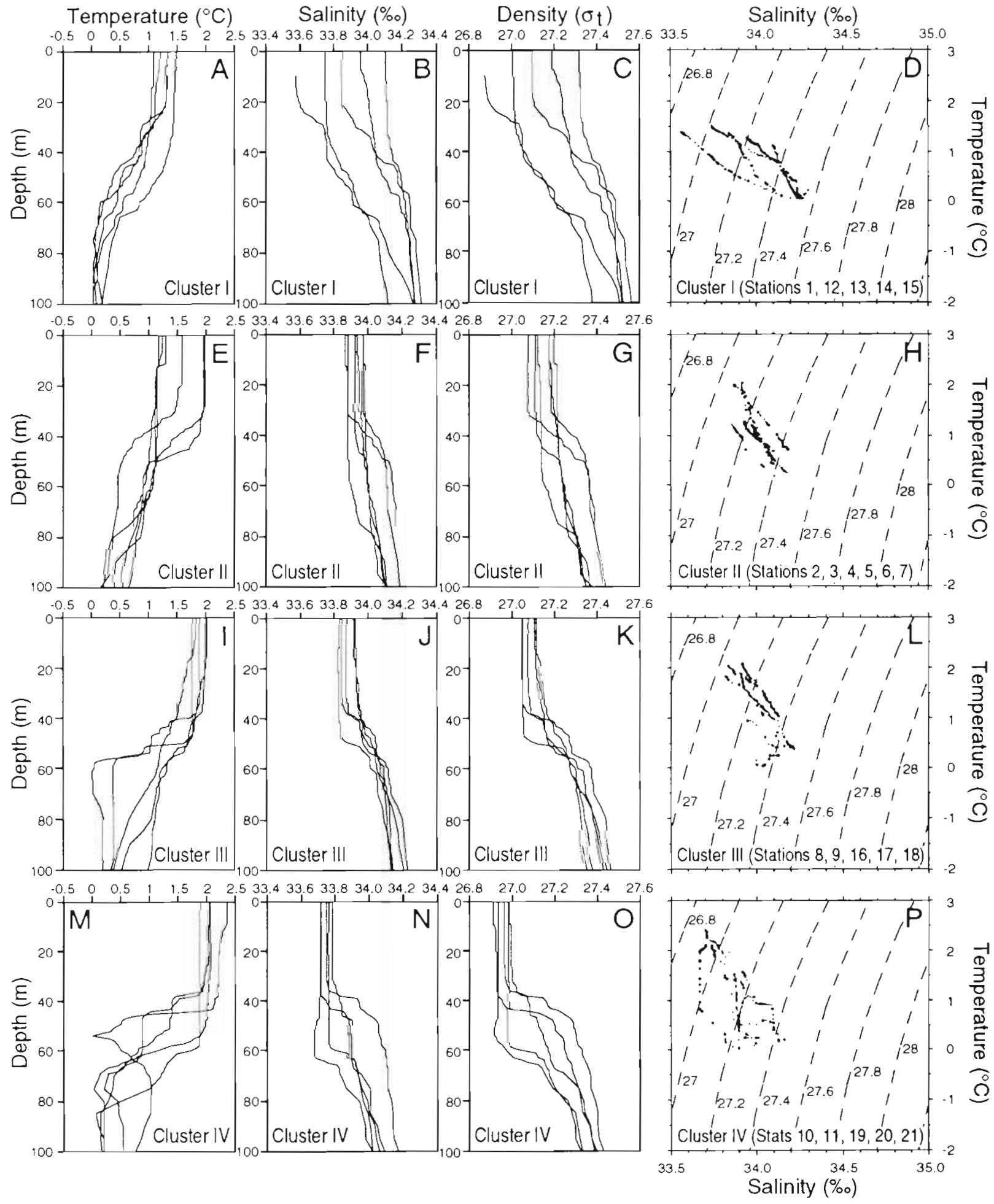

Fig. 9. Profiles of temperature, salinity, and density and temperature-salinity diagrams of the 4 clusters of Fig. 8 
tions in Cluster II (Table 3). The phytoplankton consisted mainly of nanoplankton (>95\%) such as Cryptomonas sp. (accounting for $53 \%$ of the total PPC), Phaeocystis antarctica (22\%), and diatoms (21\%) that were mostly Fragilariopsis pseudonana.

Stations located in the southern Drake Passage belong to Cluster IV (Stns 10,11,19-21). This area is north of the western South Shetland Islands (Fig. 8). The stations in Cluster IV were very different from those in Clusters I-III in that the phytoplankton consisted mainly of diatoms which accounted for more than $80 \%$ of the total PPC. The microplanktonic $(>20 \mu \mathrm{m})$ diatom species such as Rhizosolenia antennata f. semispina, Corethron criophilum, and Chaetoceros criophilum, and the nanoplanktonic $(<20 \mu \mathrm{m})$ diatom Fragilariopsis pseudonana were the most dominant species within the diatom group. Nanoplanktonic flagellates such as Cryptomonas sp., Phaeocystis antarctica, and other flagellates were present in this area but they were only $15 \%$ of the total PPC. The diatom blooms of microplankton have also been observed in Prydz Bay, where the stabilization and stratification of the surface water were induced by local atmospheric warming of the ice melt water (e.g. Kang \& Fryxell 1991).

The dominance of diatoms in the Cluster IV area seems to be due to regional features of hydrography. Correlation statistics for the relationships between the physical factors and the phytoplankton populations indicate that diatoms were more correlated with temperature, salinity, and density than flaggellates were (Table 2). Surface waters in this region are characterized by low salinity ( 33.69 to $33.78 \%$ ) and high temperature $\left(1.89\right.$ to $\left.2.36^{\circ} \mathrm{C}\right)$, and there were sigma- $t$ differences of more than 0.4 between the surface and $100 \mathrm{~m}$ depth (Fig 9M-P), leading to a strong vertical stratification of the surface water. Surface waters of the lower density are derived from Bellingshausen Sea as shown in Fig. 1A (see movement of the surface water from Hofmann et al. 1992). The continuous input from the Bellingshausen Sea of the lower-density surface waters, formed by sea ice melting and subsequent solar heating, to the northern part of the study area in the Drake Passage seems to cause the different species composition, biomass, and distribution in this area.

Regional differences of the structure of phytoplankton assemblages, whether a flagellate-dominated crop (Clusters I-III) or a diatom-dominated crop (Cluster IV), appear to reflect the differences of water mass properties. Our results suggest that these differences are due to regional features of mesoscale hydrography. Antarctic phytoplankton species dominant under certain environmental conditions could be extended to a 'marker' that distinguishes water bodies among varying hydrographic regimes.
Acknowledgements. We thank the crew and officers of the RV 'Onnuri' for the shipboard operations; Y. Kang, C. Kang, S. Ham for their assistance with sample collections; C. Chung for the analysis of nutrient samples; $J$. Kang, M. Lee for sample preparation; D. Kim and S. Kim for their support and suggestions. We also thank $O$. Holm-Hansen and 3 anonymous reviewers for critical comments on the manuscript. This work was part of the 6th Korean Antarctic Research Program (KARP) supported by the Ministry of Science and Technology in Korea (Grant PN 00183).

\section{LITERATURE CITED}

Booth BC (1993) Estimating cell concentration and biomass of autotrophic plankton using microscopy. In: Kemp PF, Sherr BF, Sherr EB, Cole JJ (eds) Handbook of methods in aquatic microbial ecology. Lewis Publishers, Boca Raton, p $199-205$

Brinton E (1991) Distribution and population structures of immature and adult Euphausia superba in the western Bransfield Strait region during the 1986-87 summer. Deep Sea Res 38:1169-1193

Buma AGJ, Gieskes WWC, Thomsen HA (1992) Abundance of Cryptophyceae and chlorophyll $b$-containing organisms in the Weddell-Scotia Confluence area in spring of 1988. Polar Biol 12:43-52

Crumpton WG (1987) A simple and reliable method for making permanent mounts of phytoplankton for light and fluorescence microscopy. Limnol Oceanogr 32:1154-1159

Dykstra MJ (1992) Biological electron microscopy. Theory, techniques and troubleshooting. Plenum Press, New York

Ferrario ME, Sar E (1992) RACER: phytoplankton populations in the Gerlache Strait. Antarct J US 27(5):158-159

Gould RW Jr (1987) The horizontal and vertical distribution of phytoplankton in warm core ring $82 \mathrm{~B}$ : a five-month time series. $\mathrm{PhD}$ dissertation, Texas A\&M University, College Station

Granéli E, Granéli W, Rabbani MM, Daugbjerg N, Fransz G, Cuzin-Roudy J, Alder VA (1993) The influence of copepod and krill grazing on the species composition of phytoplankton communities from the Scotia-Weddell sea: an experimental approach. Polar Biol 13:201-213

Grasshoff K, Ehrhardt M, Kremling K (1983) Methods of seawater analysis. Verlag Chemie, Weinheim

Helbling EW, Amos AF, Silva SN, Villafañe V, Holm-Hansen $O$ (1993) Phytoplankton distribution and abundance as related to a frontal system north of Elephant Island, Antarctica. Antarct Sci 5:25-36

Hewes CD, Holm-Hansen O, Sakshaug E (1985) Alternate carbon pathways at lower trophic levels in the Antarctic food web. In: Siegfried WR, Condy PR, Laws RM (eds) Antarctic nutrient cycles and food webs. Springer-Verlag, Berlin, p 277-283

Hewitt RP, Demer DA (1993) Dispersion and abundance of Antarctic krlll in the vicinity of Elephant Island in the 1992 austral summer. Mar Ecol Prog Ser 99:29-39

Hofmann EE, Lascara CM, Klinck JM (1992) Palmer LTER: upper-ocean circulation in the LTER region from historical sources. Antarct J US 27(5):239-241

Holm-Hansen O, Helbling EW, Lubin D (1993) Ultraviolet radiation in Antarctica: inhibition of prmary production. Photochem Photobiol 58(4):567-570

Holm-Hansen O, Mitchell BG (1991) Spatial and temporal distribution of phytoplankton and primary production in the western Bransfield Strait region. Deep Sea Res 38 961-980 
Holm-Hansen O. Riemann B (1978) Chlorophyll a determination: improvements in methodology. Oikos 30:438-447

Huntley M. Karl DM, Niiler P, Holm-Hansen O (1991) Research on Antarctic coastal ecosystem rates (RACER): an interdisciplinary field experiment. Deep Sea Res 38: 911-941

Jacobs SS, Comiso JC (1993) A recent sea-ice retreat west of the Antarctic Peninsula. Geophys Res Lett 20(12): $1171-1174$

Kang SH, Fryxell GA (1991) Most abundant diatom species in water column assemblages from five ODP Leg 119 drill sites in Prydz. Bay, Antarctica: distributional patterns. In: Barron J, Larsen B (eds) Proceedings of the ODP scientific results, 119 [Ocean Drilling Program). College Station, TX, p 645-666

Kang SH. Fryxell GA (1992) Fragilariopsis cylindrus (Grunow) Krieger: the most abundant diatom in the water column assemblages in Antarctic marginal ice-edge zones. Polar Biol 12:609-627

Kang SH, Fryxell GA (1993) Phytoplankton in the Weddell Sea, Antarctica: composition, abundance and distribution in the water-column assemblages of the marginal ice-edge zone during austral autumn. Mar Biol 116:335-348

Kang SH, Fryxell GA, Roelke DL (1993a) Fragilariopsis cylindrus compared with other species of the diatom family Bacillariaceae in Antarctic marginal ice-edge zones. Nova Hedwigia (Beih) 106:335-352

Kang SH, Suk MS, Chung CS, Nam SY, Kang CY (1993b) Phytoplankton populations in the western Bransfield Strait and the southern Drake Passage, Antarctica. Korean J Polar Res 4(2):29-43

Karentz D, Cleaver JE, Mitchell DL (1991) Cell survival characteristics and molecular responses of Antarctic phytoplankton to ultraviolet-B radiation. J Phycol 27:326-341

Kopczynska EE (1992) Dominance of microflagellates over diatoms in the Antarctic areas of deep vertical mixing and krill concentrations. J Plankton Res 14:1031-1054

Leventer A (1991) Sediment trap diatom assemblages from the northern Antarctic Peninsula region. Deep Sea Res 38: $1127-1143$

Loeb VJ, Amos AF, Macaulay MC, Wormuth JH (1993) Antarctic krill stock distribution and composition in the Elephant Island and King George Island areas, January-February, 1988. Polar Biol 13:171-181

Marchant HJ, Davidson A (1992) Possible impacts of ozone depletion on trophic interactions and biogenic vertical carbon flux in the Southern Ocean. In: Weller G, Wilson CL, Severin BA (eds) Proceedings of the international confer-

This article was presented by $O$. Holm-Hansen (Senior Editorial Advisor), La Jolla, California, USA ence on the role of polar regions in global change. Geophysical Institute, Fairbanks, A.L, p 631-635

Martin JH, Fitzwater SE, Gordon RM (1990) Iron deficiency limits phytoplankton growth in Antarctic waters. Global biogeochem Cycles 4:5-12

Medlin LK, Lange M, Baumann NEM (1994) Genetic differentiation among three colony-formung species of Phaeocystis: further evidence for the phylogeny of the Prymneslophyta. Phycologia 33:199-212

Mitchell BG, Brody EA, Holm-Hansen O, McClain C. Bishop $J$ (1991) Light limitation of phytoplankton bromass and macronutrient utilization in the Southern Ocean. Limnol Oceanogr 36:1662-1677

Mitchell BG. Holm-Hansen O (1991) Observation and modeling of the Antarctic phytoplankton crop in relation to mixing depth. Deep Sea Res 38:981-1007

Niiler PP, Amos A, Hu JH (1991) Water masses and $200 \mathrm{~m}$ relative geostrophic circulation in the western Bransfield Strait region. Deep Sea Res 38:943-959

Nöthig EM, von Bodungen B, Sui Q (1991) Phyto- and protozooplankton biomass during austral summer in surface waters of the Weddell Sea and vicinity. Polar Biol 11:293-304

Quetin LB, Ross RM (1985) Feeding by Antarctic krill, Euphausia superba: does size matter? In: Siegfried WR, Condy PR, Laws RM (eds) Antarctic nutrient cycles and food webs. Springer-Verlag, Berlin, p 372-377

Smayda TJ (1978) From phytoplankton to biomass. In: Sournia A (ed) Monographs on oceanic methodology, 6. Phytoplankton manual. UNESCO, Paris, p 273-279

Smetacek V, Scharek R, Nothig EM (1990) Seasonal and regional variations in the pelagic and its relationship to the life history cycle of krill. In: Kerry KR, Hempel G (eds) Antarctic ecosystems, ecological change and conservation. Springer-Verlag, Berlin, p 103-114

Smith RC, Prézelin BB, Baker KS, Bidigare RR, Boucher NP, Coley I, Karentz D, MacIntyre S, Matlick HA, Menziez D, Ondrusek M, Wan Z, Waters KJ (1992) Ozone depletion: ultraviolet radiation and phytoplankton biology in Antarctic waters. Science 255:952-959

Vernet M (1992) RACER: predominance of cryptomonads and diatoms in the Gerlache Strait. Antarct J US 27(5):157-158

Villafane V. Helbling EW, Holm-Hansen O (1993) Phytoplankton around Elephant Island, Antarctica: distribution, biomass and composition. Polar Biol 13:183-191

Weiler CS, Penhale PA (1994) Ultraviolet radiation in Antarctica: measurements and biological effects. Antarctic Research Series 62, American Geophysical Union, Washington, DC

Manuscript first received: February 3, 1994

Revised version accepted: April 12, 1995 